The Agriculturists 16(2):102-114(2018) ISSN 2304-7321 (Online), ISSN 1729-5211 (Print)

A Scientific Journal of Krishi Foundation

Indexed Journal

DOI: http://dx.doi.org/ 10.3329/agric.v16i02.40348

Impact Factor: 0.568 (GIF, 2015)

\title{
A Socio-economic Analysis of Private Plant Nursery Business in Bangladesh
}

\author{
Al Mamun*, Arifur Rahman and Nabihatul Afrooz \\ Research Department, Emerging Credit Rating Ltd., Dhaka, Bangladesh \\ *Corresponding author and Email: mamun.nt987@gmail.com
}

Received: 25 September 2018

Accepted: 25 December 2018

\begin{abstract}
This study was conducted to examine the socio-economic condition, profitability, and marketing channel of small-scale private plant nurseries in Bangladesh. The study is based on survey data collected from 105 respondents from the Dhaka metropolitan area, Savar Upazila and two Upazilas of Gazipur District during January-March 2018 using a structured questionnaire. The study reveals that about 74 percent of private plant nursery established on government land in Dhaka metropolitan area, whereas in Gazipur and Savar areas the nurseries are mostly on the rented property which is 68 percent and 56 percent respectively. The average land size of the nursery is 9.06 decimal in Dhaka metropolitan area, 182.06 decimal in Gazipur and 121.18 decimal in Savar area. The average length of the business is 12 years where more than 80 percent of the firms are run by sole ownership. The average annual income using per decimal land from the plant nursery business is Tk.76,411 in Dhaka, Tk.7,066 in Gazipur and Tk.10,085 in Savar. The benefit-cost ratio is 1.53, 1.51 and 1.52 per decimal for Dhaka, Gazipur and Savar areas, respectively. Usually, two intermediaries such as wholesalers and retailers are involved in the plant nursery business. Although plant nursery business is a profitable enterprise, however, the owners are facing numerous problems which need to be improved in order to the smooth expansion of the nursery business in Bangladesh.
\end{abstract}

Keywords: Bangladesh, private plant nursery, the benefit-cost ratio (BCR), profitability, marketing channel.

\section{Introduction}

Bangladesh economy has been growing at a steady pace in the last decade (WB, 2018). Despite the robust economic growth, one-third of the annual employment growth rate declined (from 3.1 percent to 1.8 percent) between 200310 and 2010-16 periods (Farole and Cho, 2017). During this period (2003-16), Bangladesh economy has generated more than 1.15 million net jobs per year on average (Farole and Cho, 2017). Within employed peoples, about 40 percent of them are underemployed, and many persons have counted as employed those are worked only a few hours a week and at low wages rate (CIA, 2018). However, people are more interested in looking for a job instead of being an investor or entrepreneur in Bangladesh. The reasons may be the lack of investment capital and investment-friendly environment (WB, 2018). Plant nursery business can be a good solution for them, because of lower investment cost, higher return and lower risk for doing the business (Haque et al., 2007).

In recent years, plant nursery business entered into a new dimension especially in Dhaka metropolitan area, where the plant nursery 
owners are selling plants as well as providing different types of services such as rooftop gardening, landscaping and so on. It is because of the significant growth of per capita income, rapid growth of urbanization, environmental degradation, and the nutritional values (BBS, 2018; Statista, 2018; ECDS, 2017). Considering the environmental issues, more and more people in metropolitan areas are spending time in the plantation on rooftops, balconies and even indoors to beautify their little corners and in some cases to meet up some nutritional demand of fresh and organic fruits and vegetables (Islam, 2002). The country requires significant numbers of plant nurseries to fulfill the enormous demand of plants both in urban and rural areas, which creates an opportunity for youth unemployed people to become an entrepreneur.

Few economic studies have been conducted on nursery business in Bangladesh (Islam et al., 1998; Haque et al., 2007), especially in urban areas (Ahmed et al., 2008). A large number of plant nurseries exist in Savar and Dhaka metropolitan area, but no economic study has been found based on these areas. Haque et al. (2007) have conducted a study in Jessore and Gazipur districts, but data had been collected 15 years ago and hence does not show the present status of nursery business. Moreover, no study has been found which emphasizes different segment such as the marketing channel of the plant nursery business. Therefore, considering these facts, this study had been conducted in Gazipuar, Savar and Dhaka metropolitan areas with objectives: i) to identify the socio-economic status of the nursery owners, ii) to estimate the profitability of nursery business, and iii) to explore the marketing channel and problems associated with the business. The findings of this study will help the researcher to do further research on this industry, and the policymakers will get a proper idea about this industry, and enable them to take appropriate policy for further improvement of the plant nursery business. Similarly, the findings of this study will help the entrepreneurs to understand the current situation of this business.

\section{Materials and Methods}

This study has collected primary data by using a Multistage Sampling method. In the first stage, using the Cluster Sampling method, Uttara, Mirpur, Dhanmondi, Sher-E-Bangla Nagar, Badda, Gulshan, Progoti Sarani-Debogram Road, and Ramna area has been selected from the Dhaka Metropolitan area. Similarly, Saver Union and Ashulia Thana have been chosen from Savar Upazila, and Rajendrapur from Kapasia and Mouchak from Kaliakair has been chosen from Gazipur District. The areas have been selected by the availability of the plant nurseries in the locality.

In the second stage, the data has been collected using the lottery method of Simple Random Sampling. Fifty-five plant nurseries have been randomly selected from Dhaka Metropolitan area; twenty-five has been selected from Kapasia and Kaliakair Upazila in Gazipur District and twenty-five nurseries from Savar Union and Ashulia Thana in Savar Upazila. ${ }^{2}$ However, the

${ }^{1}$ First, Dhaka Division has been selected from the existing eight Divisions by using Cluster Sampling method. After that Dhaka and Gazipur District has been chosen from the thirteen districts of Dhaka Division. Farther, using the same method, Dhaka Metropolitan Area and Savar Upazila has been chosen from Dhaka District and Kaliakair and Kapasia Upazila has been chosen from Gazipur District.

${ }^{2}$ In Dhaka Metropolitan area, ten out of eightyseven plant nurseries have been selected from Uttara, ten out of fifty-eight from Mirpur, five out of thirty-two from Dhanmondi, five out of twenty-eight from Sher-E-Bangla Nagar, five out of thirty-three from Badda, five out of eighteen from Gulshan, ten out of ninety-three from Progoti Sarani-Debogram Road, and finally five out of thirty-one plant nurseries has been chosen from Ramna area. In Savar Upazila, eighteen plant nurseries have been chosen from one hundred twenty-six plant nurseries from Savar Union and another seven have been chosen out 
primary data was collected randomly by prescheduled questionnaire from selected areas during January - March 2018 to fulfill the objective of this study.

Both tabular and statistical methods had been used for data analysis. The methods had been used to analyze the socio-economic profile of the plant nursery owners, land and labor distribution of the plant nurseries. The tabular method also included analysis of the Total Cost (TC) and Total Revenue (TR), net profit, Gross Margin (GM), and Benefit Cost Ratio (BCR). All the costs and returns had been calculated on a yearly basis for per decimal ${ }^{3}$ land using the formula.

$\mathrm{TC}=\mathrm{TVC}+\mathrm{TFC}$; where, TVC denoted Total Variable Cost and TFC denoted Total Fixed Cost. TFC refers to all the related fixed cost including the Opportunity Cost (OC) of the family labor and the rent of owned land, ${ }^{4}$ and TVC refers to all the variable costs of the business.

TR is the sum of selling all types of plant and related products including the services provided by plant nurseries. Net profit $=\mathrm{TR}+\mathrm{TC} ; \mathrm{GM}=$ TR-TVC and BCR = TR / TC.

Finally, this study figured the weighted scores of the problems and the recommendations by the respondents using the following formula.

Weighted Score $=\Sigma W_{\imath}$

of fifty-six plant nurseries from Ashulia Thana. From Rajendrapur of Kapasia Upazila, twenty plant nurseries have been chosen out of eightythree plant nurseries, and another five plant nurseries have been chosen out of twenty-seven plant nurseries from Mouchak, Kaliakair.

${ }^{3} 100$ decimals $=1$ acre

${ }^{4}$ The opportunity cost of the family is the cost of sacrificing wage earning from another plant nursery. Similarly, the opportunity cost of using own land is sacrificing the rent if they had given it for rent to another plant nursery.
Where, $W_{i}$ denoted the score given by the respondent for the $i^{\text {th }}$ problem, and $i=1,2,3,4 \ldots n$.

\section{Results and Discussion}

\subsection{Socio-economic profile of private plant nursery owners}

The socio-economic characteristics of the plant nursery owners of Dhaka metropolitan area, Gazipur, and Savar areas has presented in Table 1.

\subsubsection{Age of private plant nursery owners}

Age is a significant demographic factor in deciding on the operation of any business. Among the plant nursery owners, the average age has been calculated 39.58 years in Dhaka metropolitan area, 39.64 years in Gazipur and 43.52 years in Saver area. ${ }^{5}$ In Dhaka metropolitan area, more than 60 percent of the observed plant nursery owners' age varied between 30 - 40 years which indicates that the young generations in this region are showing interest in the plant nursery business. On the other hand, more than 50 percent of the owners' age varies above 40 years in Gazipur and Savar areas which show the involvement of experienced entrepreneurs in the plant nursery business in these regions.

\subsubsection{Education of private plant nursery owners}

Education makes a person more confident, secure and creates the ability to think and decide quickly. Education played an essential role in a person's income (Asadullah, 2007). Education levels of the sampled plant nursery owners vary from illiterate to graduate level. Among the respondents, 23.64 percent of the owners have no education in Dhaka metropolitan areas, which

\footnotetext{
5 In 2017, the median age was 26.7 years in Bangladesh (IndexMundi, 2018); and the estimated median age will be 27.5 by $2020,31.6$ by $2030,35.9$ by 2040 and 40 by 2050 (statista, 2018).
} 
is higher than the Gazipur (8 percent) and Savar area (12 percent). However, in Dhaka metropolitan area another 23.64 percent owners have a primary level of education, 23.64 percent have high school level of education, 12.73 percent graduated, and the rest of them have a secondary and higher secondary level of education.

Table 1. Socio-economic profile of the private plant nursery owners

\begin{tabular}{|c|c|c|c|}
\hline Characteristics & Dhaka & Gazipur & Savar \\
\hline \multicolumn{4}{|c|}{ Age of the Owners (\%) } \\
\hline Below 30 years & 21.82 & 40 & 16 \\
\hline 31 to 40 years & 41.82 & 4 & 32 \\
\hline 41 to 50 years & 23.64 & 24 & 20 \\
\hline Above 50 years & 12.73 & 32 & 32 \\
\hline Mean (SD) & $39.58(9.98)$ & $39.64(13.83)$ & $43.52(12.11)$ \\
\hline \multicolumn{4}{|c|}{ Education of the Owners (\%) } \\
\hline Illiterate & 23.64 & 8 & 12 \\
\hline Primary & 23.64 & 32 & 20 \\
\hline High School & 23.64 & 28 & 16 \\
\hline Secondary & 7.27 & 16 & 20 \\
\hline Higher Secondary & 9.09 & 16 & 12 \\
\hline Graduate $\&$ above & 12.73 & - & 20 \\
\hline \multicolumn{4}{|c|}{ Experience of the Owners (\%) } \\
\hline Below 11 years & 41.82 & 40 & 24 \\
\hline 11 to 15 years & 27.27 & 8 & 8 \\
\hline Above 15 years & 30.91 & 52 & 68 \\
\hline Mean (SD) & $13.99(8.35)$ & $15.68(11.83)$ & $21.52(9.61)$ \\
\hline \multicolumn{4}{|c|}{ Mean (SD) Family Composition } \\
\hline Average family Size & $4.75(1.75)$ & $4.40(1.91)$ & $6.96(2.86)$ \\
\hline Male & $2.58(1.20)$ & $2.64(1.25)$ & $3.84(1.72)$ \\
\hline Female & $2.15(0.99)$ & $2.08(1.29)$ & $3.60(2.38)$ \\
\hline Dependent & $2.58(1.24)$ & $2.32(1.11)$ & $2.56(2.02)$ \\
\hline Independent & $2.14(1.82)$ & $2.16(1.31)$ & $4.32(2.53)$ \\
\hline \multicolumn{4}{|l|}{ Legal institution (\%) } \\
\hline Sole Ownership & 94.55 & 84 & 92 \\
\hline Partnership business & 5.45 & 16 & 8 \\
\hline \multicolumn{4}{|c|}{ Length of Business in Present Location(\%) } \\
\hline Below 6 years & 34.55 & 40 & 24 \\
\hline 6 to 10 years & 29.09 & 16 & 20 \\
\hline Above 10 years & 36.36 & 44 & 56 \\
\hline Mean (SD) & $9.85(6.43)$ & $11.8(8.67)$ & $14.44(9.96)$ \\
\hline \multicolumn{4}{|c|}{ Ownership Pattern of Land (\%) } \\
\hline Own land & 1.82 & 20 & 16 \\
\hline Lease land & 1.82 & 12 & 28 \\
\hline Rented land & 21.82 & 68 & 56 \\
\hline Government land & 74.55 & - & - \\
\hline
\end{tabular}


On the other hand, 32 percent of the owners have a primary, 28 percent have a high school, and another 30 percent (16 percent) have a secondary and higher secondary level of education in Gazipur area. Similarly, 60 percent of the respondents (20 percent) have a primary, secondary and graduate level of education in the Savar area. Another 16 percent and 12 percent have high school and higher secondary level of education respectively. The table1 shows that people who are below the graduation level of education are mainly engaged in the plant nursery business.

\subsubsection{Experience of private plant nursery owners}

Experience is another important factor that helps an entrepreneur to run a business more efficiently and smoothly. The average experience of the respondents' in Dhaka metropolitan area has calculated 13.99 years, Gazipur 15.68 years and Savar 21.52 years, which indicates the plant nursery business run by experienced entrepreneurs in every area. The distribution of experience shows that more than 40 percent of the plant nursery owners reported having experience less than 11 years, about 31 percent have above 15 years, and the rest of them have 11-15 years in Dhaka metropolitan area. In Gazipur area, 40 percent of respondents informed that they have less than 11 years of experience in the plant nursery business. Another 52 percent owners reported having more than 15 years of experience, which is higher than the Dhaka metropolitan area (about 31 percent). In Savar area, 68 percent of respondents have more than 15 years of experience, which is higher than any other areas.

\subsubsection{Family size of private plant nursery owners}

In this study, the family is defined as people living together and eating in the same household. The hired laborers of the plant nursery business have not included as a member of the family. However, the average family size of the respondents shows 4.75 members in Dhaka metropolitan area, more than 4.40 members in
Gazipur and 6.96 members in Savar area which is higher than the average family size (4.06) of Bangladesh (BBS, 2018). Further details include, the average male numbers of the sampled family shows 2.58 members in Dhaka metropolitan area, 2.64 members in Gazipur and 3.84 members in Savar area whereas the average female members showed to be 2.15 in Dhaka metropolitan area, 2.08 in Gazipur and 3.60 in Savar area. Moreover, the average dependent and independent members of the family have been discovered in the Dhaka metropolitan area to be 2.58 and 2.14, Gazipur area to be 2.32 and 2.16, and Savar area to be 2.56 and 4.32 , respectively.

\subsubsection{Types of private plant nursery business}

This study has found two types of private plant nursery based on ownership patterns such as sole ownership and partnership. Table 1 shows that private plant nursery businesses are mainly run by sole proprietors having around 95 percent of private plant nurseries in Dhaka metropolitan area, 84 percent in Gazipur and 92 percent in Savar area.

\subsubsection{Establishment age of private plant nursery business in present location}

Establishment age of a business in the present location is crucial, especially for maintaining the relationship with customers and suppliers. In case of plant nursery business, the average establishment age in present location is found to be 9.85 years for Dhaka metropolitan area, 11.80 years for Gazipur area and 14.44 years for Savar area. However, more than 30 percent of the plant nurseries' establishment age up to 5 years in the present location, while 29.09 percent has within $6-10$ years and 34.55 percent has more than 10 years in Dhaka metropolitan area. On the other hand, 40 percent of the plant nurseries' establishment age up to 5 years in Gazipur area, and another 16 percent and 44 percent establishment age within 6-10 years and more than 10 years respectively. In Saver area, 56 percent of the plant nurseries' establishment age more than 10 years and rest of the private plant nurseries' establishment age up to 10 years. 


\subsubsection{Ownership of land}

The plant nursery owners have used four types of land for doing their business, such as own land, lease land, rented land, and government land. ${ }^{6}$ In the Dhaka metropolitan area, around 75 percent of the private plant nursery have established on government land, ${ }^{7}$ which makes the plant nurseries more vulnerable to stay in the present location. In Gazipur area 68 percent and Savar area 56 percent private plant nursery have established on rented land, while around 22 percent in Dhaka metropolitan area. However, this study has not found any evidence of using government land in Gazipur and Savar areas.

\subsection{Land distribution pattern of private plant nursery}

In this study, the average total land used in the plant nursery business has been segregated according to the ownership pattern of the land (Table 2). The average total land used under the private plant nurseries is found to be 9.06 decimal in Dhaka metropolitan area, where abandoned government land is 4.20 decimal, the rented land is 3.43 decimal, and the rest of the lands are owned and leased. In Gazipur area, on average, 182.06 decimal land (51.89 decimal owned lands, 35.70 decimal leased and 95.47 decimal rented lands) have been used by each plant nursery; and in Savar area, which is 121.18 decimal where 22.86 decimal owned land, 51.29

\footnotetext{
${ }^{6} \mathrm{~A}$ lease is a contract to rent land for one year or more. Moreover, renting typically involves a shorter period which is not more than one year (BusinessDictionary, 2013). This study has found the owners who rented the land has paid their rent on monthly basis and who leased the land, they paid the lease amount at a time based on their contract when the agreement was conducted.

7 This study revealed that the owners illegally occupied the abandoned government land and established the plant nurseries on that land. But they have to pay a significant amount of money to the law enforcement agency and local extortionists on monthly basis for the land.
}

decimal leased land and 47.04 decimal rented land.

\subsection{Labor distribution of private plant nursery}

The plant nursery business is considered a laborintensive business (Robbins, 2018). The distribution pattern of labors is shown in Table 3. It has been found that on average, 1.21, 1.16 and 1.32 family members worked in the nursery in Dhaka metropolitan area, Gazipur area, and Savar area, respectively.

This study divided permanent labor into two categories such as skilled labor and unskilled labor. ${ }^{8}$ However, the average total permanent labor is 2.09 ( 1.87 skilled and 0.22 unskilled) in Dhaka metropolitan area, 5.24 (4.24 skilled and one unskilled) in Gazipur area and 6.24 (4.80 skilled and 1.44 unskilled) in Savar area. The average total family and permanent labor have recorded 3.31 in Dhaka metropolitan area, 6.40 in Gazipua area and 7.56 in Savar area. Apart from permanent labor, the private plant nursery owners also employed temporary labors. In Gazipur area 7.86 temporary laborers have been appointed in production purpose; after that Dhaka metropolitan area and Savar have been appointed average 3.20 and 2.76 labors respectively. However, this study has not found any involvement of female family labors and permanent hired labor in the plant nursery business. Females labor have been found as temporary labor in Gazipur and Savar areas which was difficult to measure because the temporary labors worked on a daily basis. The temporary labors have been estimated by the

${ }^{8}$ According to Investopedia, "skilled labor refers to persons or positions requiring a specialized skill set to complete some of the assigned tasks. Skilled labor may have more advanced education, training or experience. On the other hand, unskilled labor is a segment of the workforce associated with a limited skill set or minimal economic value for the work performed. Unskilled labor is generally characterized by lower educational attainment and lack of training (Investopedia, 2017)." 
sum of average numbers of labors hired each month in a calendar year divided by twelve months.

\subsection{Economic analysis of private plant nursery business}

The economic exploration of the private plant nursery business includes the analysis of total costs, total revenue, net profit along with gross margin and benefit-cost ratio.

\subsubsection{Cost of private plant nursery business}

The total cost items of the private plant nursery business have included fixed costs, opportunity costs, and variable costs (Table 4). This study mainly focused on the average yearly cost of using per decimal land due to the simplicity of analysis and comparison among the areas.

The fixed costs of plant nursery business have considered the land use cost (lease land, rented land, and government land), depreciation costs of building and construction, vehicle, office equipment, machinery, and other expenses such as electricity, water supply equipment, interest payment and so on. The opportunity cost of family labor and own land also considered as the fixed cost. The average yearly total fixed cost is estimated to be Tk.25,047 in Dhaka metropolitan area, but in Gazipur (Tk.1,641) and Savar (Tk. $2,419)$ areas exhibited a significantly lower due to lower per decimal land cost. Among the fixed cost, the land cost is one of the main costs of the plant nursery business in every observed area, after that building, vehicle, office equipment, and machinery costs.

The variable cost share is the most substantial amount of the total cost of plant nursery business. The variable cost encompasses the labor costs (permanent skilled and unskilled labor), chemical fertilizers (urea, TSP, MP, DAP) cost, cow dung and oil-cake costs. Variable cost also included irrigation costs, insecticides cost, soil purchase costs, cost of earthen and others pots (plastic pot, ceramic pot, and metal and plastic drum), and cost of poly bags including others costs (electricity cost, transportation cost, and so on).

Table 2. Land distribution pattern of private plant nursery in decimal

\begin{tabular}{lcccccc}
\hline \multirow{2}{*}{ Particular } & \multicolumn{2}{c}{ Dhaka } & \multicolumn{2}{c}{ Gazipur } & \multicolumn{2}{c}{ Savar } \\
\cline { 2 - 7 } & Mean & SD & Mean & SD & Mean & SD \\
\hline Own land & 0.82 & 6.07 & 51.89 & 114.39 & 22.86 & 61.29 \\
Lease land & 0.60 & 4.46 & 35.7 & 100.05 & 51.29 & 92.53 \\
Rented land & 3.43 & 10.15 & 94.47 & 95.24 & 47.04 & 55.27 \\
Government land & 4.20 & 5.44 & - & - & - & - \\
\hline Total & 9.06 & 11.7 & 182.06 & 105.21 & 121.18 & 75.26 \\
\hline
\end{tabular}

Table 3. Distribution of labor under private plant nursery

\begin{tabular}{lcccccc}
\hline \multirow{2}{*}{ Particular } & \multicolumn{2}{c}{ Dhaka } & \multicolumn{2}{c}{ Gazipur } & \multicolumn{2}{c}{ Savar } \\
\cline { 2 - 7 } & Mean & SD & Mean & SD & Mean & SD \\
\hline Family labor male & 1.21 & 0.46 & 1.16 & 0.37 & 1.32 & 0.48 \\
Permanent hired skilled labor & 1.87 & 2.26 & 4.24 & 3.42 & 4.80 & 3.97 \\
Permanent hired unskilled labor & 0.22 & 0.69 & 1.00 & 1.68 & 1.44 & 1.78 \\
Total permanent hired labor & 2.09 & 2.34 & 5.24 & 4.88 & 6.24 & 4.32 \\
Total family \& permanent labor & 3.31 & 2.32 & 6.40 & 5.07 & 7.56 & 4.37 \\
Temporary labor & 3.20 & 3.32 & 7.68 & 4.88 & 2.76 & 2.71 \\
\hline
\end{tabular}


Table 4. Analysis of yearly costs and returns for per-decimal land

\begin{tabular}{|c|c|c|c|}
\hline \multirow{2}{*}{ Particulars } & Dhaka & Gazipur & Savar \\
\hline & Value (Taka) & Value (Taka) & Value (Taka) \\
\hline \multicolumn{4}{|l|}{ A. Fixed Cost } \\
\hline (i) Lease Land & 218.23 & 250.08 & 510.04 \\
\hline (ii) Rented Land & $2,226.34$ & 513.67 & 461.91 \\
\hline (iii) Government Land & $4,519.48$ & - & - \\
\hline (iv) Buildings & 252.66 & 22.17 & 21.92 \\
\hline (v) Vehicles & 635.26 & 1.53 & 50.17 \\
\hline (vi) Office Equipment & 28.56 & 1.18 & 1.06 \\
\hline (vii) Machineries & 77.54 & 44.18 & 48.46 \\
\hline (viii) Opportunity Cost of Family Labor & $16,255.23$ & 690.76 & $1,184.35$ \\
\hline (ix) Opportunity Cost of Rent & 240.82 & 79.09 & 90.31 \\
\hline (x) Others & 592.41 & 38.61 & 50.50 \\
\hline Total Fixed Cost & $25,046.53$ & $1,641.27$ & $2,418.72$ \\
\hline \multicolumn{4}{|l|}{ B. Variable Cost } \\
\hline \multicolumn{4}{|l|}{ (i) Labor Cost } \\
\hline (a) Permanent Labor Skill & $12,679.11$ & 582.67 & 920.94 \\
\hline (b) Permanent Labor Unskilled & $1,396.75$ & 129.19 & 265.39 \\
\hline (c) Temporary Labor & $2,048.16$ & 177.83 & 87.14 \\
\hline (ii) Cow Dung & $4,995.55$ & 624.42 & 795.53 \\
\hline (iii) Oil-Cake & 367.37 & 32.17 & 50.54 \\
\hline (iv) Urea & 134.98 & 6.72 & 11.17 \\
\hline (v) TSP & 292.04 & 54.41 & 71.50 \\
\hline (vi) MP & 113.31 & 16.29 & 18.02 \\
\hline (vii) DAP & 391.28 & 73.08 & 119.01 \\
\hline (viii) Irrigation & $1,180.01$ & 35.59 & 50.50 \\
\hline (ix) Insecticides & 351.60 & 41.13 & 50.90 \\
\hline (x) Soil & $7,889.22$ & $1,195.39$ & $1,490.15$ \\
\hline (xi) Earthen Pot \& Others Pot & $17,724.24$ & $2,971.33$ & $4,169.40$ \\
\hline (xii) Poly Bags & $3,549.67$ & $1,427.00$ & $1,871.60$ \\
\hline (xiii) Others & 590.00 & 55.37 & 61.40 \\
\hline (xiv) Owned Seed/ Seedling & $6,538.23$ & $1,183.79$ & $1,350.72$ \\
\hline (xv) Purchased Seed/ Seedling & $54,641.72$ & $3,622.54$ & $5,082.03$ \\
\hline Total Variable Cost & $1,14,883.23$ & $12,228.91$ & $16,465.94$ \\
\hline C. Total Cost $(A+B)$ & $1,39,929.76$ & $13,870.18$ & $18,884.66$ \\
\hline
\end{tabular}

Note: (i) 1 US\$ = 84Taka (October, 2018)

The cost of seed/ seedling (owned and purchased) also included in the calculation of variable costs. The average total variable cost is estimated to be Tk.114,883 in Dhaka metropolitan area, Tk.12,229 in Gazipur area and Tk.16,466 in Savar area. The total variable cost is significantly higher in the Dhaka metropolitan area compared to the other areas; because a large volume of sales has been conducted using per decimal land. However, the most significant variable cost has come from purchased seed/ seedlings after that purchasing earthen and other 
pots - the cost of labor, soil, owned seed/ seedling, fertilizers and insecticides, and the cost of poly bags also the significant variable costs for plant nursery business. However, the total cost is the sum of total fixed cost and total variable cost. The total cost has estimated about Tk.1,39,930 in Dhaka metropolitan area, Tk.13,870 in Gazipur area and Tk.18,885 in Savar area.

\subsubsection{Gross total revenue, net profit, and household income}

The income of the sampled private plant nursery owners is generated from selling the fruit plants, flower and ornamental plants, wood and medicinal plants, and providing different types of services (rooftop gardening, landscaping etc.), along with selling related products such as fertilizers, soil, insecticides, earthen and other pots, and so on. Average revenue, net profit and total household income from each plant nursery using per decimal land are shown in Table 5. The private plant nursery owners have received the highest average revenue from selling the fruit plants, after that from selling flower and ornamental plants, and then wood and medicinal plants. The plant nursery owners in the Dhaka metropolitan area also earn a significant amount of revenue to provide related services and selling associated products compared to Savar and Gazipur area. The nursery owners have earned average total revenue using per decimal land is Tk.213,594 Dhaka metropolitan area, Tk.20,964 in Gazipur area, and Tk. 28,724 in Savar area. The estimated net profit for each plant nursery is Tk.73,664, Tk.7,094, and Tk.9,839 for Dhaka, Gazipur, and Savar area, respectively. Generally, Fruit plants have sold throughout the year, but in winter the volume of sales is decreased significantly.

Table 5. Yearly total revenue and net profit for per-decimal land

\begin{tabular}{lccc}
\hline \multirow{2}{*}{ Sources of Income } & Dhaka & Gazipur & Savar \\
\cline { 2 - 4 } & Per Decimal & Per Decimal & Per Decimal \\
\hline A. Revenue & & & \\
(i) Fruit Plants & $99,939.74$ & $14,171.15$ & $18,181.22$ \\
(ii) Flower \& Ornamental plants & $69,295.63$ & $5,655.28$ & $8,318.20$ \\
(iii) Wood \& Medicinal Plants & $1,300.42$ & 715.81 & 847.66 \\
(iv) Services and others & $43,058.41$ & 421.84 & $1,376.46$ \\
B. Total Revenue & $\mathbf{2 , 1 3 , 5 9 4 . 2 0}$ & $\mathbf{2 0 , 9 6 4 . 0 8}$ & $\mathbf{2 8 , 7 2 3 . 5 5}$ \\
C. Net Profit & $\mathbf{7 3 , 6 6 4 . 4 3}$ & $\mathbf{7 , 0 9 3 . 9 0}$ & $\mathbf{9 , 8 3 8 . 8 9}$ \\
\hline
\end{tabular}

Note: (i) 1 US $\$=84$ Taka (October, 2018)

Table 6. Gross margin, and benefit bost ratio (BCR) for per-decimal land

\begin{tabular}{lccc}
\hline \multirow{2}{*}{ Particulars } & Dhaka & Gazipur & Savar \\
\cline { 2 - 4 } & Value (Taka) & Value (Taka) & Value (Taka) \\
\hline 1. Total Revenue & $2,13,594.20$ & $20,964.08$ & $28,723.55$ \\
2. Total Variable Cost & $1,14,883.23$ & $12,228.91$ & $16,465.94$ \\
3. Total Cost & $1,39,929.76$ & $13,870.18$ & $18,884.66$ \\
4. Gross Margin (GM) & $98,710.97$ & $8,735.17$ & $12,257.61$ \\
5. Net Profit & $76,410.80$ & $7,065.78$ & $10,085.33$ \\
6. Benefit Cost Ratio (BCR) & 1.53 & 1.51 & 1.52 \\
\hline
\end{tabular}

Note: (i) 1 US $\$=84$ Taka (October, 2018) 
On the other hand, the sales volume of flower plants increases significantly in the winter season. However, it is evident that the plant nurseries in Dhaka metropolitan area have earned significantly higher than Gazipur and Savar areas due to the comparatively higher selling price and providing different services.

\subsubsection{Gross margin (GM) and benefit cost ratio (BCR)}

Table 6 shows that Gross Margin (GM) and Benefit Cost Ratio (BCR) of the sampled private plant nurseries. In the Dhaka metropolitan area, the average gross margin is Tk.98,711, and the average BCR is 1.53 for each plant nursery. In Gazipur area, the average gross margin for each farm is estimated to be Tk.8,735, and the average BCR is 1.51. Finally, in Savar area, the average gross margin is Tk.12,258, and the BCR is 1.52 from each farm. So, it can be concluded that plant nursery business is highly profitable in every study area.

\subsection{Marketing channels of private plant nursery business}

The marketing channel of plant nursery business has been delineated in Figure 1. Generally, two intermediaries such as wholesalers and retailers are involved in the plant nursery business. A plant nursery owner either produces plants or purchase plants from other plant nurseries. All the plant nurseries are involved in the production and both in retail and wholesale activities except retail nurseries. The retail plant nurseries are mainly involved in retail selling and some of the productions. The owners of the retail-wholesale plant nurseries buy plants directly from the producers and sell it either to the other wholesalers and retailers or directly to the customers. The retailers purchase plants from producers and sell it directly to the customers.

\subsection{Problems and constraints of private plant nursery owners}

The opinions of the respondents have been collected regarding the problems of plant nursery business. The owners have provided different information about this issue (Table 7). In Dhaka metropolitan area, about 90 percent of the owners have expressed dissatisfaction for their dishonest employees, mainly for financial matters. More than 70 percent of plant nursery owners have used government land which made their business vulnerable because the government forces them to leave their land. About 84 percent of respondents have ensured an inadequate supply of land is a problem of a plant nursery business. The scarcity of skilled labors is another significant problem, which has confirmed 82 percent of the respondents. The main reason for this problem is that employees are willing to works in the industrial sector rather than in the agriculture sector.

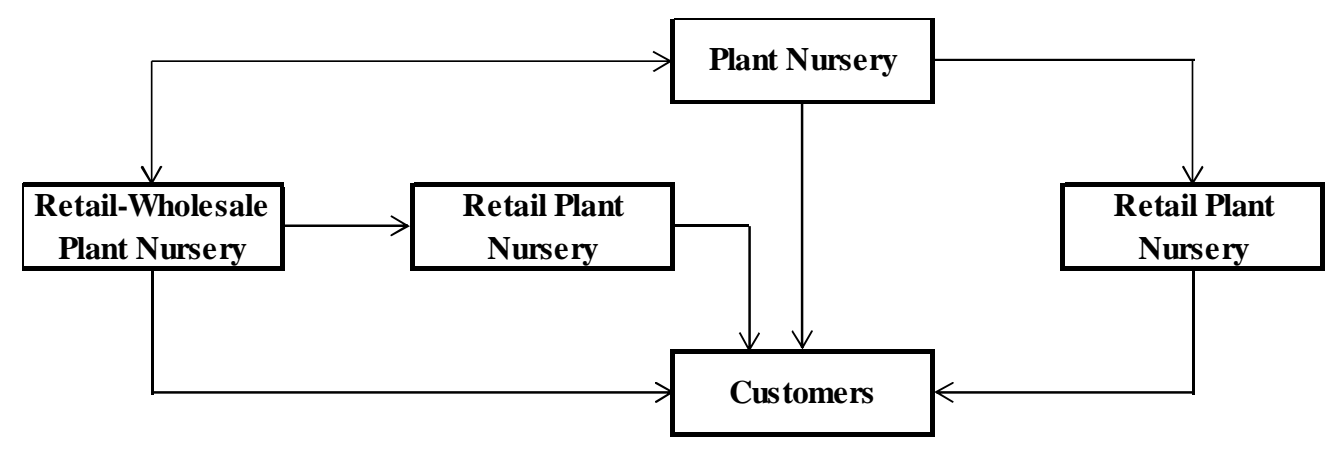

Fig. 1. Marketing channels of private plant nursery business 
Table 7. Problems faced by private plant nursery owners

\begin{tabular}{lccc}
\hline Problems & $\begin{array}{c}\text { Dhaka } \\
(\boldsymbol{\%})\end{array}$ & $\begin{array}{c}\text { Gazipur } \\
(\boldsymbol{\%})\end{array}$ & $\begin{array}{c}\text { Savar } \\
(\boldsymbol{\%})\end{array}$ \\
\hline Inadequate fund & 16 & 48 & 36 \\
Lack of credit facilities & 26 & 44 & 56 \\
Lack of technical knowledge & 64 & 20 & 28 \\
Inadequate supply of land & 84 & 12 & 16 \\
Availability of skilled labor & 82 & 72 & 84 \\
Availability of exquisite quality plant and seeds & 38 & 64 & 68 \\
Insufficient power and water supply & 76 & 24 & 32 \\
Weather (flood, heavy rain) & 24 & 92 & 80 \\
Frequent insects attack & 32 & 76 & 72 \\
Lack of training program & 10 & 16 & 28 \\
Lack of government support & 44 & 8 & 16 \\
The honesty of the employees & 90 & 68 & 76 \\
\hline
\end{tabular}

Table 8. Suggestions of private plant nursery owners

\begin{tabular}{lccc}
\hline Suggestions & $\begin{array}{c}\text { Dhaka } \\
(\boldsymbol{\%})\end{array}$ & $\begin{array}{c}\text { Gazipur } \\
(\boldsymbol{\%})\end{array}$ & $\begin{array}{c}\text { Savar } \\
(\boldsymbol{\%})\end{array}$ \\
\hline Need government support & 62 & 28 & 52 \\
Require easy loan program & 14 & 56 & 64 \\
Establish community basis permanent zones for the plant nurseries & 36 & - & - \\
Require effective training program & 76 & 68 & 64 \\
Effective government monitoring system & 10 & - & - \\
Established plant nursery beside the main road & 44 & 24 & 16 \\
Make sure the quality of plants & 36 & 84 & 80 \\
Keep domestic plants in the nursery & - & 52 & 44 \\
Use better quality soil for plants & 10 & 40 & 28 \\
Hire expert employees & 82 & 76 & 84 \\
\hline
\end{tabular}

About 76 percent of the respondents informed that lack of power and water supply is a problem, and 64 percent told that lack of technical knowledge is also a problem. The plant nursery owners also faced other problems such as lack of government support, availability of quality plants and seeds, insects, lack of credit facilities, and weather problem (flood, heavy rain).

In Gazipur area, about 92 percent of respondents reported that heavy rain and flood destroy their plants in rainy season. About 76 percent mentioned that insects hamper the plants; about 72 percent faced skilled labor problem, and 68 percent concern about the honesty of their employees. Similarly, about 64 percent of the owners have mentioned that lack of quality plants and seeds is another major problem. About 48 and 44 percent of respondents reported a lack of fund and lack of credit facilities hampered their business respectively. In addition to this, some owners also faced insufficient power and water supply (24 percent) problem, lack of technical knowledge (20 percent) problem, unavailability of the training programs (16 percent) problem, inadequate supply of land (12 percent) and lack of government support (8 percent) problem. 
In Savar area, most of the owners ( 88 percent) have faced skilled labors problem. About 80 percent of owners told about the flood problem and massive rain problem; about 76 percent informed the issue of employees' honesty, and 72 percent mentioned the insect's problem. Similarly, about 68 percent confirmed a shortage of quality plants and seeds problem; about 56 percent told about lack of credit facilities problem, and 36 percent reported the insufficient fund is a problem. Besides, the owners also faced the problem of insufficient power and water supply (32 percent), lack of technical knowledge (28 percent), lack of training program (28 percent), lack of land supply (16 percent) and lack of government support (16 percent).

\subsection{Suggestions}

The sampled owners provided some suggestions regarding overcoming the problems faced by the plant nursery owners for smooth production and marketing that has been presented in Table 8. In Savar area, about 84 percent of owners have suggested that expert labors are required to make the business profitable and smooth operation. A similar suggestion has provided by 82 percent owners of Dhaka metropolitan area and 76 percent in Gazipur area. About 76 percent of owners in the Dhaka metropolitan area, 68 percent owners in Gazipur area and 64 percent owners in Savar area have suggested to organizing regular training program. The main reason is that if the government provides the available training programs, the owners will able to produce quality seedling and plants, along with increase technical knowledge.

About 62 percent owners in Dhaka metropolitan area and 52 percent owners in Savar area have claimed that they need government support regarding financial and technical issues. About 84 percent owners in Gazipur, 80 percent in Savar and 36 percent in Dhaka metropolitan area have advised the plant nursery owners to provide quality plants to the customers for the growth of this industry. About 52 percent owners in Gazipur area and 44 percent owners in Savar area have advised that the domestic plants should be sale beside exotic plants. More than 50 percent of the plant nursery owners in Gazipur and Savar area have suggested that the government should provide an easy bank loan for the entrepreneurs to recover the shortage of funds. Less than 50 percent owners of all areas have suggested that the entrepreneurs should make sure the quality soil for the healthy plants, and should establish the plant nursery beside the main road for the transportation, sale, and marketing related issues. Less than 40 percent of the owners in Dhaka metropolitan area expected that government would support to establish community basis permanent zones for the plant nurseries business and develop the monitoring system.

\section{Conclusions}

The findings of the study revealed that young, educated and experienced entrepreneurs are involved in the plant nursery business. Moreover, the business is economically profitable in every observed area. The average net profit of each plant nursery, using per decimal land, is estimated to be Tk.76,411 in Dhaka metropolitan area, Tk.10,085 in Savar and Tk.7,066 in Gazipur. The benefit-cost ratio is calculated to be 1.53 for Dhaka, 1.52 for Savar and 1.51 for Gazipur. Two intermediaries wholesalers and retailers are involved in the marketing channel. The study also found that owners are facing different socio-economic problems, which hamper this business, and they have proposed some solutions in this regard.

The low level of investment and a higher rate of return can be an opportunity for the entrepreneurs. The government support like comfortable credit facilities and training program to the owners could help to mitigate their financial problem, improve their management ability, production quality and capacity. Moreover, the establishment of communitybased permanent zones for the plant nurseries, especially in Dhaka metropolitan area, will ensure smooth business operation, benefit consumers and the country's ecological balance. 


\section{References}

Ahmed R., Hasan MS., Halim MA., Alam M. 2008. State of Urban Nurseries in Bangladesh: A Case Study from the North-Eastern Region. Small-scale Forestry, 7(3\&4):275-283.

Asadullah MN. 2006. Returns to Education in Bangladesh. Education Economics, 14(4):453-468.

BBS, 2018. Labour Force Survey (LFS) 201617. Report, Bangladesh Bureau of Statistics (BBS), Statistics and Informatics Division, Ministry of Planning, Parishankhyan Bhaban, E-27/A, Agargaon, Sher-e-Bangla Nagar, Dhaka1207.

BBS, 2018. National Accounts Statisticians. Report, Bangladesh Bureau of Statistics (BBS), Statistics and Informatics Division, Ministry of Planning, Parishankhyan Bhaban, E-27/A, Agargaon, Sher-e-Bangla Nagar, Dhaka1207.

Business Dictionary, 2013. Lease vs. Rent. http://www.businessdictionary.com/article /1063/lease-vs-rent-d1412/, 14 January 2019.

CIA, 2018. The World Factbook. https://www.cia.gov/library/publications/t he-world-factbook/fields/2129.html, $\quad 08$ December 2018.

ECDS, 2017. Environment, Climate Change and Disaster Statistics (ECDS) Cell. Bangladesh Environmental Statistics Framework (BESF) 2016-2030. Report, Bangladesh Bureau of Statistics, Statistics and Informatics Division, Ministry of Planning, Government of the People's Republic of Bangladesh.

Farole T., Cho Y. 2017. Bangladesh Jobs Diagnostic: Overview. Report, World Bank, Washington, DC. License: Creative Commons Attribution CC BY 3.0 IGO.

Haque M., Miah MM., Rashid M. 2007. An economic study of plant nursery business in Gazipur and Jessore districts of Bangladesh. Bangladesh Journal of Agricultural Research, 32(3):375-385.

IndexMundi, 2018. Bangladesh Demographics Profile 2018 https://www.indexmundi.com/bangladesh/ demographics_profile.html, 08 December 2018.

Investopedia, 2017. Unskilled Labor. https://www.investopedia.com/terms/u/un skilled-labor.asp, 14 January 2019.

Islam KS. 2002. Rooftop gardening as a strategy of urban agriculture for food security: The case of Dhaka City, Bangladesh. International Conference on Urban Horticulture 643, 2-6 September 2002, UASW, Waedenswil (Switzerland), 241247 pp.

Islam SS., Kibria MG., Chowdhury MH. 1998. Financial analysis of agroforestry trial at Ichamati, Chittagong. Bangladesh Journal of Forest Science, 27(2):76-81.

Robbins, JA. 2018. Starting a Wholesale Nursery - Part I. https://www.uaex.edu/publications/PDF/F SA-6055.pdf, 14 January 2019.

Statista, 2018. The Statistics Portal. Median age of the population in Bangladesh 2015. https://www.statista.com/statistics/438196 /average-age-of-the-population-inbangladesh/, 08 December 2018.

Statista, 2018. The Statistics Portal. Urbanization in Bangladesh 2016. https://www.statista.com/statistics/455782 /urbanization-in-bangladesh/, $\quad 08$ December 2018.

WB, 2018. Bangladesh Development Update. Document, The World Bank Office, Dhaka, Plot E-32, Agargaon, Sher-eBangla Nagar, Dhaka - 1207, Bangladesh.

WB, 2018. Doing Business 2019. A World Bank Group Flagship Report, The World Bank, 1818 H Street NW, Washington, DC 20433, USA. 